PISSN 2508-1640 EISSN 2508-1667 an open access journal

East Asian Economic Review vol. 22, no. 3 (September 2018) 243-273

http://dx.doi.org/10.11644/KIEP.EAER.2018.22.3.344

\title{
'Behind-the-Border' Regulatory Policies and Trade Agreements*
}

\author{
Bernard Hoekman \\ European University Institute and CEPR \\ Bernard.Hoekman@EUI.eu
}

\begin{abstract}
A consequence of global trade liberalization is that domestic regulatory policies have become a focal point for efforts to reduce the costs of engaging in cross-border production and exchange. This article discusses the general challenges of reducing trade frictions created by regulatory differences, focusing specifically on the role trade agreements might play in addressing regulatory spillovers. A case is made for a greater focus on plurilateral cooperation under the umbrella of the WTO.

Keywords: Nontariff Measures, Regulation, Regulatory Cooperation, WTO, Trade Agreements

JEL Classification: F13, F23, F53
\end{abstract}

\section{INTRODUCTION}

With the establishment of the World Trade Organization (WTO) in 1995, much of the vision of the drafters of the 1948 International Trade Organization (ITO) Charter was realized, albeit some 50 years later. ${ }^{1}$ The average level of tariffs for OECD member countries has fallen to the $3 \%$ range; for major emerging economies like China and India as well as many developing countries the average applied tariff is less than $10 \%$. In conjunction with the abolition of most of the quantitative

* This paper draws on ongoing research with Charles Sabel. An earlier version appeared online as Hoekman (2017). Thanks are due to constructive suggestions by three anonymous referees.

1 The ITO was supposed to complement the World Bank and the International Monetary Fund in the area of trade-related policy, but never entered into force as a result of a decision by the US government not to submit the treaty for approval by the Congress.

(c) Korea Institute for International Economic Policy 
import restrictions to trade that were prevalent through the 1980s, policies to open markets to direct investment - including through privatization, and technological changes that greatly reduced the costs of international communications and transport, the result has been major changes in the structure of global production and trade. One illustration of this change is the increasing share of global value chains (GVCs) in international production and the associated trade in intermediate parts, components and tasks.

Policy-induced market access frictions and trade costs today are increasingly regulatory in nature. The rapidly changing composition of trade as a result of technical changes - reflected not only in supply chains that span many countries, but the growth in services trade and cross-border data flows associated with the servicification and digitization of products (the "Internet of things") is moving national regulation to center stage in trade debates. The associated agenda is not about deregulation what is driving concerns in the business community are the trade-impeding (costraising) effects of differences in applicable domestic health, safety, privacy and data security standards, prudential and licensing requirements, certification and compliance assessment procedures for both products and production processes used by suppliers of goods and services.

Since its creation WTO members have found it very difficult to negotiate new rules of the game. Disagreements among countries regarding the benefits of committing to additional trade policy disciplines, most notably between the United States and other OECD nations on one side and emerging economies such as Brazil and India on the other, have impeded progress on the WTO's traditional market access agenda (mostly tariffs and agricultural support) and in turn blocked substantive discussion on the trade effects of domestic regulatory policies. Continued deadlock in the WTO starting in 2008 led to the focus of attention in addressing international regulatory spillovers shifting to other fora - notably preferential trade agreements (PTAs). Examples of recent initiatives with a significant focus on regulatory matters include the negotiations on a Trans Pacific Partnership (TPP) between 12 Pacific countries and the Transatlantic Trade and Investment Partnership (TTIP) between the EU and the US that were launched in 2013.

Both the TTIP and TPP initiatives illustrate that such new vintage agreements are difficult to conclude. TTIP talks were put on hold by the US at the end of 2016, and one of the first actions of the Trump Administration in early 2017 was to withdraw from TPP. However, deep PTAs that span regulatory matters continue to be pursued 
by major trading nations. Examples include the Comprehensive Economic and Trade Agreement (CETA) between Canada and the EU which entered into force in 2017, 2 the 2018 EU-Japan Economic Partnership Agreement and the successful conclusion of talks between eleven of the original signatories of the TPP to establish a Comprehensive and Progressive Agreement for Trans-Pacific Partnership (CPTPP).

Pursuit of regulatory cooperation and related rules of the road is a second-best solution, given that the organization of production and trade into GVCs and international production networks means that end products are impacted by many regulatory jurisdictions. PTAs almost by definition will not span all the countries involved in many (most) GVCs, thus limiting the positive impact that they can have in addressing regulatory differences and uncertainty for firms and consumers, while at the same time giving rise to the possibility that PTA-based regulatory initiatives may generate trade and investment diversion. Trade agreements are not the only game in town to address regulatory spillovers. Governments may and have pursued different types of regulatory cooperation efforts, ranging from sector-specific initiatives such as mutual recognition agreements (MRAs) to cross-sectoral, "horizontal" efforts that center on "practice" and learning from international experience and more formal mechanisms such as the Canada-US Regulatory Cooperation Council (Canada, 2014) that operate independently of a prevailing trade agreement (i.e. NAFTA).

What follows discusses the general challenges confronting international regulatory cooperation from the perspective of reducing trade frictions. Section 1 defines the task confronting policymakers and develops a typology of the types of initiatives that can be used to reduce negative trade spillovers created by regulatory differences. Section 2 discusses the question what role a trade agreement might play in addressing regulatory spillovers, something that arguably has not been considered seriously

2 http://international.gc.ca/trade-commerce/trade-agreements-accords-commerciaux/agr-acc/ceta-aecg/texttexte/toc-tdm.aspx?lang=eng. (accessed December 10, 2017) Only two chapters of CETA deal with reductions in import tariffs and the removal of discrimination in government procurement that is, classic market access issues where there are direct restrictions on the ability of foreign companies to supply products. The majority of the substantive chapters of CETA deal with product regulation, customs procedures, trade facilitation, policies affecting specific services sectors, mutual recognition of professional qualifications, domestic regulation more generally, procedures for regulatory cooperation and dialogue, and sector-specific protocols (e.g. on the mutual acceptance of the results of the conformity assessment of good manufacturing practices for pharmaceutical products). 
enough by the trade community. Section 3 briefly reviews some of the extant disciplines and provisions in the WTO that have a bearing on domestic regulatory policies. Section 4 does the same for recent PTAs. Section 5 suggests some limited initiatives that could be pursued under WTO auspices or in a plurilateral trade setting. Section 6 concludes.

\section{DIMENSIONS OF REGULATORY COOPERATION}

Competition between regulatory regimes is the default situation in international relations, with different jurisdictions independently applying their own set of regulations to products and producers. While competition implies differences in applicable standards across countries, over time, as learning occurs, there may be incentives to emulate more successful approaches and norms, generating convergence over time. Competition is a powerful discovery mechanism and a force that will help to identify more efficient forms of regulation to achieve a given objective. But competition may also have adverse outcomes. The commonly expressed fear of a "race to the bottom" is one possibility, albeit one for which there is generally little evidence. A much more frequent consequence of competition are excess costs associated with different regulatory regimes that have similar objectives. In such cases there are potential gains from cooperation.

International regulatory cooperation is difficult. There have been long-standing transatlantic efforts to cooperate on regulatory matters, with only limited success (Vogel, 2012). The most progress has been achieved in the EU in the context of creating a single European market for goods and services, as this required overcoming the trade-impeding effects of differences in product market regulation. This was pursued through a variety of approaches, ranging from harmonization of new regulations to mutual recognition (Pelkmans, 2012). ${ }^{3}$ The EU is of course sui generis. The

${ }^{3}$ Mutual recognition involves agreement that products legally introduced into the commerce of one jurisdiction may be sold and consumed without additional controls in another jurisdiction. To take the example of food safety standards, mutual recognition between A and B implies that A recognizes

(C) Korea Institute for International Economic Policy 
more general challenge confronting the trade community is to identify approaches to reducing trade costs through regulatory cooperation in the absence of a political commitment to fully integrate markets and without supranational institutions that are tasked with reducing the market segmenting effects of national policies.

In principle, addressing this challenge should be facilitated if regulatory objectives are equivalent across countries and economies have similar income levels. Approaches may differ towards reducing risk and avoiding catastrophic events, but if goals are very similar, regulatory cooperation may reduce compliance costs without undercutting the attainment of national regulatory objectives. The agenda here is not just about reducing compliance costs for firms and thus prices for consumers. More important is that cooperation enhances the effectiveness as well as the efficiency of regulation. Cooperation must be a mechanism that improves regulatory outcomes over time in all participating jurisdictions (Hoekman and Sabel, 2017). It may well be that improving regulatory effectiveness and efficiency will also reduce costs. More generally, improving regulatory coherence across countries is likely to lower trade costs by enhancing transparency and information on applicable regulatory norms. A basic question for policymakers is how best to design international regulatory cooperation so that it enhances regulatory performance and lowers trade costs. This requires knowledge about both the potential benefits and the political feasibility of cooperation.

Figure 1 distinguishes between the magnitude of net economic gains from regulatory cooperation and the political and technical difficulty (cost) of implementing the necessary cooperation. In principle, cooperation should center on areas that fall into the bottom-right cell $D$ and on efforts to move items from $C$ to $D$. As important is to avoid investing resources in regulatory areas that fall into box A. Mapping policy areas into these different categories cannot simply be based on technical analysis but requires active engagement by regulators, business and consumers. Regulators should be interested in those activities and initiatives that increase their ability to achieve their mandate more effectively and efficiently. Business presumably would like to see compliance costs fall, while citizens and consumers may worry

that the norms prevailing in B satisfy its own safety norms and vice versa. If the underlying norms in the two jurisdictions differ enough, such an approach is not feasible. Even if A and B harmonize their norms, trade still might be affected by redundant costs if both continue to inspect products before they are allowed to be sold. Only if A and B mutually recognize (accept) that their respective enforcement systems are effective will harmonization eliminate regulatory trade costs. 
that cooperation will erode regulatory standards, resulting in a "race to the bottom." This is a major factor underlying the resistance by some civil society groups in the EU, Korea and other nations to PTAs that involve "deep integration" (see, for example, Cardoso et al., 2013 on fears that a TTIP could do so). The result of these different entry points implies that not all issues will lend themselves equally to cooperation. Insofar as the areas of concern fall into boxes $C$ or $D$, a precondition for cooperation is to address the worries of either regulators and/or consumers that make an issue area politically sensitive. But efforts to do so through joint learning and interaction should prioritize areas that offer the highest potential economic benefits. In some instances this may not be possible; in others it may require a substantial amount of time to establish the needed understanding and trust to allow cooperation to occur. There is therefore a dynamic time dimension to this two-bytwo matrix.

Figure 1. Net Economic Payoffs and Feasibility of Cooperation

\begin{tabular}{|c|c|c|c|}
\hline & & \multicolumn{2}{|c|}{ Political/technical costs } \\
\hline \multirow{3}{*}{ Net economic benefits } & & High & Low \\
\cline { 2 - 4 } & Low & $A$ & $B$ \\
\hline & High & $C$ & $D$ \\
\hline
\end{tabular}

Various approaches have been pursued to attenuate international regulatory spillovers (OECD, 2013). These include seeking to converge over time on the substance of new regulatory norms (harmonization and international standardization), accepting differences in regulation and focusing on putting in place processes to address negative spillover effects of such differences through mutual recognition agreements or determinations of regulatory equivalence, and efforts to increase "coherence" across regulatory regimes. The latter generally center on identifying good practices and basic principles such as transparency, consultations with stakeholders, use of impact assessments, and so on. ${ }^{4}$

4 There is of course an extensive literature on the various options and experiences; see for example, Vogel (2012) and OECD (2014). Much of the focus will (have to) be sector specific; see, for example, Arnold (2005), Bismuth (2010) and Verdier (2011) for analyses of services regulation.

(C) Korea Institute for International Economic Policy 
Cooperation can be characterized along a spectrum of "soft" to "hard" depending on how binding (enforceable) the commitments are, with agreements ranging from "shallow" to "deep" depending on whether they entail commitments not to do something or go beyond that to require positive action. Efforts to increase coherence across regulatory regimes are an example of "soft" cooperation. They have been a central element of international initiatives on regulation pursued in the OECD and APEC, which focus on principles and processes as opposed to the substance of regulation.

"Shallow" types of cooperation may be limited to commitments to enhance the transparency and visibility of extant regulation and new regulatory initiatives, or they may go further and involve creation of processes through which parties inform and/or consult each other or commit to providing opportunities for comment before adopting new regulations. Some instances of "shallow" regulatory cooperation may be relatively straightforward to apply to a large number of countries, as they are in the nature of focal points and guidance for national policy. Whether or not a country implements the principles or good practices will not have a direct effect on the realization of regulatory goals in another nation.

Deeper forms of regulatory cooperation have implications for the realization of regulatory objectives - they create interdependence between jurisdictions: the attainment of a regulatory goal in country $A$ becomes a function of actions by country $B$. Deeper forms of cooperation span a range of possibilities, from harmonization at one extreme - i.e. adopting the same norms - to (mutual) recognition agreements or acceptance of the equivalence of regulatory regimes.

Figure 2 illustrates different types of regulatory cooperation and lists a number international institutions and fora that have been created to support their implementation. There are many examples of both "shallow" and "deep" regulatory cooperation the ones mentioned in Figure 2 are just illustrative. ${ }^{5}$ Many (most) of these do not involve trade agreements, but some do. The alternative approaches can all be embedded

5 Major international regulatory/standards-setting bodies include the Codex Alimentarius Commission, the International Electrotechnical Commission, the UN Economic Commission for Europe (UNECE), the International Organization for Standardization (ISO), the International Air Transport Association (IATA), the International Accounting Standards Board (IASB), the International Telecommunications Union (ITU), the Basle Committee on Banking Supervision, the Financial Stability Board (FSB), the International Organization of Securities Commissions (IOSCO) and the International Association of Insurance Supervisors (IAIS). 
into trade agreements. There are several mentions of the WTO in Figure 2, reflecting the fact that its multilateral agreements - GATT, GATS and TRIPS - make references to harmonization (international standardization) and/or mutual recognition agreements, even if there is no legal obligation imposed on all WTO members to harmonize their norms or to recognize those of trading partners (the WTO status quo is discussed below).

Figure 2. A Typology of Regulatory Cooperation and Illustrative Examples

\begin{tabular}{|c|c|c|c|}
\hline & Global & Plurilateral & Bilateral \\
\hline \multicolumn{4}{|c|}{ 'Shallow' cooperation } \\
\hline Coherence & $\begin{array}{l}\text { BCBS, UNCITRAL, ISO; } \\
\text { ICN; WTO }\end{array}$ & $\begin{array}{l}\text { OECD, APEC, GPA; } \\
\text { GATS (Telecom } \\
\text { Reference Paper) }\end{array}$ & BITs \\
\hline Consultation & $\begin{array}{l}\text { OIE, IOSCO, WHO, } \\
\text { WTO: TBT/SPS }\end{array}$ & EU; G20 & RCC (Canada-US) \\
\hline \multicolumn{4}{|c|}{ 'Deeper' forms of cooperation } \\
\hline $\begin{array}{l}\text { Recognition } \\
\text { (MRAs) }\end{array}$ & CIPM; ILAC; IAF & $\begin{array}{c}\text { EU-US (various); } \\
\text { ASEAN (various); ... }\end{array}$ & $\begin{array}{l}\text { US-Australia (securities); } \\
\text { Trans-Tasman MRA }\end{array}$ \\
\hline Equivalence & SPS (WTO) & $\mathrm{EU}$ & $\begin{array}{c}\text { EU-US air safety; } \\
\text { ANZCERTA }\end{array}$ \\
\hline $\begin{array}{c}\text { International } \\
\text { Standardization }\end{array}$ & $\begin{array}{l}\text { UNECE, Codex } \\
\text { Alimentarius; IMF; } \\
\text { GlobalGap; VSS }\end{array}$ & FSB, ESMA, EU, ICH & RCC (new regulations) \\
\hline
\end{tabular}

Notes: ANCERTA: Australia-New Zealand Closer Economic Relations Trade Agreement; BCBS: Basle Committee for Banking Supervision; BIT: bilateral investment treaty; CIPM: International Committee for Weights and Measures; FSB: Financial Stability Board; GPA: WTO Government Procurement Agreement; IAF: International Accreditation Forum; ICH: International Conference on Harmonization of Technical Requirements for Registration of Pharmaceuticals for Human Use; ICN: International Competition Network; ILAC: International Laboratory Accreditation Cooperation; OIE: World Organization for Animal Health; RCC: Regulatory Cooperation Council; $\boldsymbol{V S S}$ : voluntary sustainability standards.

Coherence involves efforts among jurisdictions to ensure that the regulatory process conforms to what are generally accepted to be good practices: e.g., ensuring that regulation is transparent; that there is the opportunity for stakeholders, including foreign firms and governments, to comment on proposed new regulations, or that the process of regulatory development should be informed by an economic impact assessment or a cost/benefit analysis. The aim here is not to question or discuss the objectives or the substance of regulation. Instead the focus is on the process through 
which regulation is developed and implemented. Coherence is an important element of WTO disciplines on sanitary and phytosanitary (SPS) measures and technical barriers to trade (TBT) and has been the focus of work programs in organizations such as the OECD, various UN bodies and APEC for many years.

Consultation goes beyond joint efforts to define and implement good practices (coherence) and begins to engage with the substance of regulation and its spillover effects. Examples include the scope that has been created in the WTO to raise specific trade concerns (STCs) regarding (proposed) TBT and SPS measures (Wijkström, 2015) and the framework that has been established for consultations on regulatory matters through the Canada-US Regulatory Cooperation Council (RCC).

Deeper forms of cooperation go further in seeking to reduce the market-segmenting effects of differences in regulation across countries. Examples are agreements to (mutually) recognize a foreign regulatory process, efforts between regulators to determine instances where regulatory regimes are equivalent, and efforts to adopt common regulatory standards or conformity assessment processes - i.e. harmonization of norms. Such deeper forms of regulatory cooperation are difficult to achieve for a number of reasons. There may be (i) mandate gaps, in that domestic regulators are not permitted to pursue cooperation or have not been given the resources to do so; (ii) coordination gaps in instances where international cooperation requires several regulatory agencies within a country to work together; or (iii) informational gaps within and across countries, such as a lack of data on how a regulatory regime “works” (Hoekman, 2015). Addressing these gaps requires institutions and processes that foster regular communication and repeated interaction. This is needed both across agencies within countries - frequently multiple regulators and government bodies are engaged in setting and enforcing product and process regulations - and across countries. This is non-trivial, especially in federal states, where regulation is applied at the state level (for example, in 13 provinces and territories in Canada, 29 states in India and 50 states in the US). In the case of the EU, the 28 member states continue to have significant autonomy in the implementation of regulation in many areas.

Regulators frequently have their own mechanisms through which they interact with each other internationally. Governments at different levels (central, sub-central, municipal), regulators and international businesses are all engaged in mechanisms that entail cooperation with counterparts across borders (jurisdictions). Lead firms set standards for quality, health and safety for both products and processes that 
occur in their supply chains. They may cooperate in private standards-setting activities that have as a goal achievement of inter-operability and minimum standards across supply chains. They may work in cooperation with non-governmental organizations (NGOs) and governments to do so (and example being the Global Food Safety Initiative). NGOs do the same - there is a plethora of different private standards-setting bodies that develop norms and offer certification services to companies that engage in international trade. The characterization of levels of "regulatory" cooperation in Figure 2 also applies to the world of private standards, as is illustrated by the inclusion of several such initiatives.

\section{WHAT ROLE FOR TRADE AGREEMENTS?}

A key question for policymakers is whether, given a presumption that there are good reasons for pursuing regulatory cooperation, this should be embedded in trade agreements. Given a rationale for regulatory cooperation, what is the value added of tying this to a trade agreement as opposed to simply giving regulators a mandate to interact and work together to improve regulatory requirements and processes? Assuming policymakers determine it is useful to embed regulatory cooperation into trade agreements, an ancillary question is whether this is best pursued through the multilateral forum (the WTO), through PTAs or both. In practice the answer is likely to depend on the feasibility of engaging in cooperation with a large number of countries (regulators), the payoffs of doing so for each participating entity and the extent to which idiosyncratic domestic regulatory regimes give rise to trade costs for international businesses. These are very much open questions to which this article will not provide answers. What is clear however is that the type of factors discussed briefly in the previous section will play an important role.

Trade agreements are designed to reduce explicit discrimination against foreign suppliers of goods and services. An implication is that traditional sector-specific regulation that entails barriers to entry lends itself to the reciprocal bargaining and market access commitments that are the core feature of trade agreements. As such regulation can be "captured" by incumbent firms who use their political influence to ensure that they have favorable treatment (Stigler, 1975), a very similar dynamic as that underpinning trade negotiations can be used to reform such types of regulation.

(C) Korea Institute for International Economic Policy 
However, while entry-restricting regulation continues to exist for some sectors especially in some services - in the 1980s and 1990s regulation changed in nature. Regulation is no longer dominated by efforts to control the behavior of firms in sectors in which entry is restricted. ${ }^{6}$ Instead, the focus is on ensuring that markets are contestable and on the use of market conduct and liability rules that are (supposed to be) applied equally to domestic and foreign goods and services to do so, complemented by mechanisms to elicit revelation of information by firms on their costs (Laffont, 1994; Posner, 2013).

The source of regulatory trade costs lies in differences in regulations across jurisdictions and the need to comply with the requirements of multiple regulatory bodies in different countries. As already noted, reducing the market-segmenting effects of differences in regulations is difficult because of concerns that it may compromise countries' regulatory objectives and hinder the execution of regulatory agencies' legal mandates and obligations. This implies that reciprocal commitments to change national policies — the bread and butter of trade agreements - often simply will not be feasible. The nature of regulation is technical and dynamic, involving many actors with different degrees of autonomy and decentralization; moreover, regulators will respond to differences in local circumstances and changes in knowledge over time. This makes it difficult — indeed, undesirable — to 'negotiate' substantive changes in regulation or to impose regulatory harmonization or convergence by fiat. Instead, regulatory cooperation must be premised on mutual assessments of performance of regulatory regimes to enable regulators to assure principals (stakeholders, legislatures) that the other party has effective systems in place. In practice, convergence, if it occurs at all, will most likely be gradual, with partner countries over time moving closer to systems that are constructed and implemented the same way.

The increasing complexity and interdependence of modern economies that is reflected in the growth in collaborative international production networks (GVCs) has led to forms of what has been called meta-regulation (Coglianese and Mendelson, 2010). Meta-regulation involves the establishment of monitoring and learning regimes.

\footnotetext{
${ }^{6}$ A caveat to this is that state-owned or state-controlled enterprises continue to be prevalent in many countries. Insofar as this is associated with barriers to entry for investment by foreign-owned companies, trade agreements can be used as instruments through which to seek to impose market disciplines on such entities.
} 
Instead of presuming that regulators should define uniform rules based on scientific evidence, the aim of meta-regulation is to create incentives for companies to invest resources in regular collection and analysis of data to identify and mitigate specific risks they either confront or may generate. Such approaches are salient in the context of GVCs. For example, ingredients contaminated with pathogens are periodically introduced into global food supply chains and widely propagated as the adulterated foodstuffs are incorporated into diverse batches of processed products. The inadvertent co-production of hazards by firms that are part of international networks - often identifiable years after products have entered commerce-calls for regulatory approaches that recognize such possibilities and that are designed to generate and disseminate relevant data to all parties concerned on a timely basis (Hoekman and Sabel, 2017).

As a result of the type of uncertainty that accompanies GVC-based production and extensive cross-border flows and interdependence, the regulatory problem becomes one of organizing and supervising joint investigation by firms of emergent risks and responding to them before they cause harm. This is a problem that calls for approaches that involve data collection, data analysis and data sharing. An example is the use of hazard analysis of critical control points (HACCPs) for pathogens, implemented on both sides of the Atlantic, involving a mix of administrative action, legislation and private standards (Sabel and Simon, 2011; Humphrey, 2012).

From a trade policy perspective the emerging shift towards meta-regulation raises the question whether and how trade agreements can support this type of regulatory cooperation. To date, efforts in this direction in recent trade agreements such as the CPTPP and CETA have centered on provisions calling for regulatory coherence. Going beyond this is perhaps less obvious than often seems to be assumed. Trade agreements can be characterized as purposeful efforts to align the behaviors of key players (governments in particular, and through them, regulatory agencies) in a top-down manner, i.e., by inclusion of provisions requiring government entities to behave in a specific way - or more frequently, not to engage in certain practices. However, insofar as regulation increasingly revolves around a decentralized effort at problem solving - i.e. bottom-up mechanisms - a potential role for trade agreements to support regulatory cooperation is by acting as a device to support credible commitments to pursue a bottom-up approach centered on problem-solving by creating an institutional framework that promotes and supports this. Whether trade agreements can be designed to do so is an open question - one that has not 
been the subject of much research. There are many examples of meta-regulation that spans regulatory agencies in multiple countries, but these tend to emerge outside the contours of trade agreements. ${ }^{7}$

Perhaps the most straightforward case for using trade agreements is that this will help ensure that the trade effects of regulation are considered explicitly. Regulators often do not consider the international implications of what they do. To a large extent this is simply because they are not called to do so by their authorizing environment. They may be limited in their appreciation of the economic effect and costs associated with implementation of their regime on firms and consumers in other jurisdictions. A necessary condition for regulators to consider the (cross-border) economic implications of their work is that they have incentives to do so, which raises issues related not just to their legal mandates but also the design of institutional mechanisms that facilitate learning and a better understanding of the overall impact of regulatory norms on trade and investment incentives. In terms of the typology of Figure 1, a trade agreement may help in identifying which areas of regulation fall into boxes $C$ and $D$.

Trade agreements may also be used as an instrument to generate the political oversight needed for implementation of cooperation. An important feature of trade agreements is that there are a large number of interests represented. This can not only ensure that areas that are priorities from a trade perspective are identified and put on the table, but also help overcome political economy constraints that preclude movement in a direction that governments perceive will enhance aggregate welfare. Regulators may have a vested interest in the status quo, or have been captured by a domestic industry. Focusing on such problems in a trade agreement context may help mobilize the political support needed to push through reforms. Referring back to Figure 1, dealing with regulatory matters in a trade agreement may help move forward over time on issues that are in boxes $C$ and $D$.

${ }^{7}$ Hoekman and Sabel (2017) discuss specific examples, including the Bilateral Aviation Safety Agreement between the EU and the US. This covers principally the airworthiness of equipment from design to manufacture and maintenance, as well as conformity to environmental standards, and is a comprehensive framework governing mutual recognition of air safety certification systems. It includes a formal structure for dispute resolution and allows for possible extension to new areas of air safety. 
Addressing regulatory issues in a trade agreement also may benefit regulators if it helps to mobilize additional resources to support cooperation. This can both support greater attention being given to cooperation - as that will entail a resource cost for the agencies involved - and, indirectly but potentially importantly, allow for a reallocation of scarce resources to other areas. That is, if cooperation is successful - for example, it results in acceptance that two regimes are equivalent - regulators can allocate less to surveillance of that particular issue area and focus more on other concerns. The benefits of regulatory cooperation accrue not just to companies and consumers in the form of lower compliance costs; if it results in reductions in operating costs for a regulatory agency, this will release resources for other purposes.

The feasibility of international regulatory cooperation will depend on the countries that pursue it. Developing countries with more limited capacity to design and implement regulatory policies to ensure the safety of products or discipline the economic behavior of firms may be constrained in their ability to engage in even the shallowest forms of cooperation. In practice many developing countries will be 'rule-takers', having to adopt and comply with standards set either through international processes in which they have little if any capacity to engage, or by large developed countries. This may give rise to conflicts insofar as the norms concerned are not optimal from the perspective of the developing country. The scope for this will be attenuated if standards are set through international mechanisms in which many countries participate. Trade agreements can help move countries towards adoption of international standards and regulatory norms by making this a principle or objective of the agreement. They can also help address capacity differentials and weaknesses that impede the ability to apply basic principles such as transparency, notification and allowing for comment from stakeholders on proposed new regulation. Resource constraints can be overcome through technical assistance and capacity-building activities aimed at improving regulatory systems and governance in developing nations. Including commitments in trade agreements to provide assistance to support regulatory cooperation can help to pit in place the preconditions for developing nations to participate and benefit from regulatory cooperation. The 2013 WTO Trade Facilitation Agreement (TFA) provides an example ${ }^{8}$

${ }^{8}$ Implementation of TFA disciplines by developing countries can be made conditional on provision of technical and financial assistance from high-income countries. See e.g., Hoekman (2016).

(C) Korea Institute for International Economic Policy 


\section{THE WTO STATUS QUO}

In principle, the WTO is the global apex institution through which governments can seek to address cross-border spillovers created by national trade-related policies. The primary focus in the WTO is on trade policies, but the agreement also spans disciplines on domestic regulation, motivated by a concern that these not be used to discriminate against foreign products and undercut liberalization commitments. The national treatment rule is a general obligation for goods, whereas it is a specific one in the case of services - applying only to scheduled services/modes of supply. The WTO does not engage on the substance of regulatory measures-all it requires is that foreign products are treated the same as domestic ones. The WTO does embody some disciplines that require minimum levels of regulation - for example, the TRIPS agreement requires Members to implement minimum standards of protection for intellectual property - but the substance of the rights and requirements/criteria involved are left to other international bodies to determine.

Concerns that product-specific regulatory norms may be used for protectionist purposes has motivated the negotiation of specific disciplines that go further than the national treatment rule. The main examples are the Agreement on Technical Barriers to Trade (TBT) and the Agreement on Sanitary and Phytosanitary (SPS) Measures. The TBT agreement addresses technical requirements (mandatory regulatory norms) imposed by governments for goods; the SPS agreement deals with mandatory health and safety-related norms for agricultural products (foodstuffs, plant and animal health). The TBT agreement goes further than national treatment by requiring that Members base their product regulation on available international standards (whenever appropriate) and adopt the least trade-restrictive measure that is necessary to achieve their regulatory objective. ${ }^{9}$ The SPS agreement makes explicit reference to an indicative list of international bodies that promulgate SPS norms, such as the Codex Alimentarius Commission. If a national product-specific regulatory measure is based on an international standard, it is presumed to satisfy the least trade-restrictive test in that the norms are

9 What follows focuses on the TBT agreement. Similar considerations apply to the SPS agreement. 
considered to be necessary and non-discriminatory in effect and in intent. ${ }^{10}$ Whether this is in fact the case is another matter, as in practice the process of international standardization may not devote much attention to trade effects. The presumption is that because many countries will be involved in the process of defining international standards, whatever is agreed is regarded as being non-discriminatory in intent, no matter the actual effect on trade. As argued below, this is one weakness of the current approach in the WTO towards international standardization.

Many of the standards that confront firms operating internationally address management processes and production methods. Systems such as ISO 9000, ISO 14000 and ISO 26000 are used by companies as a signal of quality, a demonstration of a commitment to social responsibility or as requirements that must be met by suppliers in a trade relationship with buyers or by companies that are part of international value chains and production networks. Standards of this type are not covered by the WTO as they are not mandatory.

Conformity assessment procedures for technical product regulations are also subject to WTO disciplines, including the non-discrimination rule. Relevant guides or recommendations issued by international standardizing bodies are to be used if they exist, except if inappropriate for national security reasons or deemed inadequate to safeguard health and safety. In principle, WTO Members are free to join and use international systems for conformity assessment. The results of conformity assessment procedures undertaken in exporting countries must be accepted if consultations determine these are equivalent to domestic ones. WTO members are encouraged to negotiate MRAs for conformity assessment procedures, and not to discriminate between foreign certification bodies in their access to such agreements.

The SPS and TBT Committees have been characterized as technical expertdriven catalysts for multilateral dialogue, providing a forum for the development of guidance (soft law) and peer review of trade measures (Wijkström, 2015). An

${ }^{10}$ One reason why there are two product standards agreements is that the health and safety concerns that arise in the production, trade and consumption of food, plant life and animals are considered to be particularly important. In effect, many SPS norms can be characterized as measures that are aimed at catastrophe avoidance - the spread of diseases, the probability of serious illness, and so on. Such considerations also arise with technical barriers to trade as these may have similar motivations - e.g. a ban on the use of lead paint, radioactive residues, etc. - but they often address other types of issues as well (e.g. radio frequency interference, interoperability, and so forth).

(C) Korea Institute for International Economic Policy 
important dimension of what the WTO does in the area of product regulation is compiling information on new measures. WTO Members are required to notify the WTO of new measures that are not based on international standards. Over 45,000 measures have been notified since 1995. The TBT and SPS committees have developed procedures that can used by governments to raise concerns they have regarding proposed or applicable product standards of another WTO member. This has come to be known as the "specific trade concerns" (STC) procedure (Horn et al., 2013). Between 1995 and 2015, over 800 STCs pertaining to SPS or TBT measures were raised in the relevant committee, implying that fewer than $2 \%$ of notified measures raised concerns. This process is widely regarded as being a useful mechanism to address concerns raised - about $40 \%$ of STCs in the area of SPS have reportedly been resolved (WTO, 2015). Over time the STC mechanism has evolved - for example, in 2014 WTO Members agreed to a procedure through which they can seek the services of the Chair of the SPS Committee or another facilitator to help find a solution to their concerns. ${ }^{11}$

Much prevailing regulation deals with services. The WTO has fewer disciplines for regulations affecting services than for goods (product regulation). Article VI.4 of GATS calls on the Council for Trade in Services to develop any necessary disciplines to ensure that measures relating to qualification requirements and procedures, technical standards and licensing requirements do not constitute unnecessary barriers to trade in services, ${ }^{12}$ and Members may not apply regulatory requirements so as to nullify or impair specific commitments made for sectors/modes (Article VI.5(a)). The GATS therefore embodies a weak "least trade-restrictive" norm, but there is no obligation to use international standards - WTO Members may use whatever standards they wish.

GATS Article VII (Recognition) promotes the establishment of procedures for (mutual) recognition of licenses, educational diplomas and experience granted by

11 See https://www.wto.org/english/news_e/news14_e/sps_10sep14_e.htm. (accessed December 10, 2017)

12 A Working Party on Domestic Regulation was mandated to develop disciplines called for by Article VI:4 to ensure that licensing and qualification requirements and related standards are not unnecessary barriers to trade in services. A precursor to this working party, the Working Party on Professional Services, agreed in 1998 on a set of principles to ensure transparency of regulations pertaining to licensing of accountants and accountancy services.

(C) 2018 East Asian Economic Review 
a particular Member. It permits a Member to recognize the standards of one or more Members, but does not require, or even encourage, Members recognize equivalent foreign regulations. Article VII:2 requires a Member who enters into a mutual recognition agreement (MRA) to afford adequate opportunity to other interested Members to negotiate their accession to such an agreement or to negotiate comparable ones. Article VII:3 stipulates that a Member must not grant recognition in a manner which would constitute a means of discrimination between countries. Members must inform the Council for Trade in Services about existing MRAs and of the opening of negotiations on any future ones. Most such notifications pertain to the recognition of educational degrees and professional qualifications obtained abroad.

The WTO does little at present to support regulatory cooperation on a multilateral basis; the focus has been on national policies. This has included deliberations (in the context of the TBT Committee) on what constitutes good regulatory practice and options that governments can use to streamline the way regulations are prepared, adopted and applied through the "regulatory lifecycle." An example is the deliberation that commenced in 2012 over voluntary guidelines that would reduce the possibility of product regulation having the effect of unnecessarily restricting trade. However, to date no agreement on a set of good practice guidelines has proved possible because of concerns that the Appellate Body might invoke such norms in a dispute, notwithstanding the fact that it would be explicit that they would be non-binding. ${ }^{13}$

There is much more to be said about the state of play in the WTO on regulatory matters. The foregoing brief snapshot makes clear that the WTO is more involved than might be expected, but that many areas of regulation are not subject to multilateral rules of the game - especially service sector regulation. The role of the WTO as a transparency mechanism is much better developed for product regulation than it is for other types of regulation that have an impact on trade. The various committees and working parties dealing with different dimensions of economic regulation have acted as foci for deliberation and information exchange. More can certainly be done if governments are willing to do so, but the experience over the last decade

13 The Appellate Body has held that a 2000 decision by the TBT Committee on a set of (voluntary) principles for the development of international standards, guides and recommendations was a "subsequent agreement" under the Vienna Convention on the Law of Treaties; see Wijkström and McDaniels (2013).

(C) Korea Institute for International Economic Policy 
or so with attempts to refine and expand disciplines on domestic regulation of services and to agree to voluntary principles of good practice for regulation illustrates that achieving a consensus in these areas may not be possible. As far as regulatory cooperation is concerned, one shortfall in the approach taken in the WTO has been the absence of a concerted effort by WTO Members to encourage international standardizing bodies to consider the trade effects of the norms that they develop (Hoekman and Mavroidis, 2016).

\section{REGULATORY COOPERATION IN PTAs}

How do PTAs compare to the WTO? There is of course huge heterogeneity, but most PTAs do not do much more than the WTO, while the one outlier, the EU, goes far beyond the WTO in the area of regulatory cooperation. The only other PTA that includes substantial regulatory cooperation in specific areas is the AustraliaNew Zealand Closer Economic Relations Trade Agreement (ANZCERTA) (Steger, 2012). The CPTPP does not go very far beyond the WTO - the value added primarily involves language aiming at greater coherence of regulatory regimes of the signatories (Bollyky, 2012), along with provisions calling for consultations (i.e. the shallow forms of cooperation discussed in Section 1). ${ }^{14}$

The EU has used a mix of approaches to remove the market-segmenting effects of national product regulation, including harmonization and mutual recognition. The latter became a key driver following decisions of the European Court of Justice, which ruled that, in the absence of overriding concerns that permit an exception, EU members must accept products into their markets that have been legally introduced into the commerce of another member state. However, the EU experience illustrates that mutual recognition requires some minimum level of harmonization of norms (common "essential requirements"). ${ }^{15}$

${ }^{14}$ However, the CPTPP includes more detailed and far-reaching provisions on specific areas of regulation, notably with regard to digital trade and data localization. It also incorporates innovative provisions permitting data flows that were linked to (conditional on) action by exporting countries to protect privacy and prevent fraud.

15 See Pelkmans (2012) for an in-depth discussion. 
Recent PTAs involving the EU complement mutual recognition with efforts to move towards mutual "equivalence." This involves agreement that the regulatory objectives of the parties involved are equivalent and acceptance that implementation and enforcement mechanisms in the parties' jurisdictions are effective. Under a "standard" mutual recognition approach, $A$ satisfies itself that $B$ achieves its norms through the similar kind of testing, inspections, sampling and so on that $A$ undertakes. Under regulatory equivalence, $A$ simply accepts $B$ 's processes and systems: each government agrees that the regulatory regime of the other party is equivalent to its own in terms of both objectives and the effectiveness of the institutional apparatus through which these objectives are pursued. ${ }^{16}$ A necessary condition for an equivalence approach is trust: there must be a prior process of "mutual assessment" (Messerlin, 2014) or evaluation of the regulatory goals and implementation regime in the relevant jurisdictions that results in a judgment that these are "equivalent."

CETA - at the time of writing the most recent of the new type of trade integration agreements — includes some language on equivalence (Government of Canada, 2017). CETA calls for the establishment of a regulatory cooperation forum to facilitate and promote the realization of the objectives laid out in Chapter 21 on regulatory cooperation. The chapter provides that the parties may consult with stakeholders, including the research community, NGOs and business and consumer organizations "on matters relating to the implementation of" the regulatory cooperation chapter (Article 21.8). Article 21.2 commits both parties to developing their regulatory cooperation to prevent and eliminate unnecessary barriers to trade and investment; enhancing the climate for competitiveness and innovation, including through pursuing regulatory compatibility, recognition of equivalence and convergence; and adopting transparent, efficient and effective regulatory processes that better support public policy objectives and fulfil the mandates of regulatory bodies. Article 21.3 mentions such objectives of regulatory cooperation as building trust; deepening mutual understanding of regulatory governance and obtaining from each other the benefit of expertise and perspective to improve

${ }^{16}$ A key difference, therefore, is that regulatory equivalence requires a willingness to step back from a focus on technical product considerations and to assess systems as a whole. Thus, whereas mutual recognition means assessing country B's meat inspection system on the basis of a sampling regime and the results of testing in country A of a sample of products originating in B, an approach based on regulatory equivalence would justify trust in a partner country's products on the basis of systemic arguments.

(C) Korea Institute for International Economic Policy 
regulatory proposals; promoting the transparency, predictability and efficacy of regulations; identifying alternative instruments; recognizing the associated effects of regulations; and improving regulatory implementation and compliance.

Another objective of CETA is to facilitate bilateral trade and investment by reducing unnecessary differences in regulation and identifying new ways of cooperating in specific sectors. In a similar vein, the agreement mentions the complementary goal of enhancing the competitiveness of industry by looking for ways to reduce administrative costs and duplicative regulatory requirements, and "pursuing compatible regulatory approaches including, if possible and appropriate, through: a) the application of regulatory approaches which are technology-neutral, and b) the recognition of equivalence or the promotion of convergence” (Article 21.3(d)(iii); emphasis added).

Language on - and examples of - regulatory equivalence embodied in CETA include Chapter 5 on SPS measures, which requires each signatory to accept the measures of the exporting party as equivalent to its own if the exporting party “objectively demonstrates that its measure achieves the importing Party's appropriate level of protection” (Article 5.1). Guidelines for the determination of equivalence are set out in Annex 5.D to the SPS chapter, while Annex 5.E lists areas where the parties have agreed there is equivalence. One function of the CETA Joint Management Committee for SPS Measures is to prepare and maintain a document detailing the state of discussions between the parties on their work on recognizing the equivalence of specific SPS measures. A separate Protocol on the Mutual Recognition of the Compliance and Enforcement Programme regarding Good Manufacturing Practices for Pharmaceutical Products provides for the determination of the equivalence of regulatory authorities that certify compliance with these practices. Annex 1 (on Medicinal Products or Drugs) of this protocol lists products for which the parties have agreed that their requirements and compliance programs are equivalent. ${ }^{178}$

CETA Chapter 21 (on regulatory cooperation) creates an entry point with respect to greater use of regulatory equivalence among like-minded countries, but puts

17 Some mention of regulatory equivalence also occurs in the chapter on financial services, a sector where the approach has been pursued internationally for some time; see, for example, Verdier (2011). The chapter permits Canadian institutions to provide portfolio management services to EU professional clients on a cross-border basis (that is, without having to establish in the EU) once the European Commission has adopted the equivalence decision related to portfolio management (EU prudential requirements will still apply). 
little emphasis on the use of equivalence as a way to reduce regulatory differences and costs. Indeed, the chapter, while laying out a rather long illustrative list of possible cooperation activities, does not mention "equivalence" in Articles 21.4, 21.5 or 21.7. Article 21.4(r) does call for identifying approaches to reduce the adverse effects of existing regulatory differences on trade, including "when appropriate, through greater convergence, mutual recognition, minimising the use of trade distorting regulatory instruments, and use of international standards," but the activities listed in these articles focus on transparency and data and information sharing.

Even though CETA goes further than the CPTPP on regulatory cooperation, it arguably does too little to reflect the changes in the way international trade is organized. More rapid progress in attenuating the trade-cost effects of different regulatory policies might be realized by creating processes and institutional mechanisms that take a broader value chain perspective (Hoekman, 2015). Concrete initiatives to reduce the costs of redundant regulatory requirements and processes must be policy specific - that is, they must involve the type of cooperation called for in CETA and that is already being pursued in the Canada-US Regulatory Cooperation Council. But missing from current approaches are cross-cutting, supply chain-informed deliberative mechanisms that focus on a broad range of policies that affect trade costs and that provide a framework for regulatory cooperation to improve the competitiveness and efficiency of industry - two goals that Canada and the EU set for themselves in the CETA chapter on regulatory cooperation (CETA Article 21.2(4)(b)).

\section{REDUCING THE NEGATIVE TRADE EFFECTS OF BEHIND-THE-BORDER REGULATION}

Regulatory measures generally fulfil a specific social or economic purpose, even if the effect is to restrict trade. Addressing possible trade-reducing (distorting) effects of regulation requires first an understanding of the effects of prevailing (proposed) policies. Many desirable reforms will not require actions by other governments (trading partners), but regulatory cooperation may help in identifying what such reforms should seek to do and increase the effectiveness and efficiency of regulation. Trade agreements may help by mobilizing and sustaining political attention and thereby overcome resistance by vested interests and incentivize regulatory bodies to give more of a priority to actions that reduce the negative trade impacts of regulation. 
As already discussed, trade agreements are geared towards the negotiation of enforceable policy commitments. Binding disciplines reduce uncertainty for traders who know that the dispute settlement mechanism can be used to ensure that governments live up to what they sign on to. A precondition for agreement on binding international rules is a shared recognition that the negative spillovers associated with a policy (or set of policies) are significant and that a proposed set of (enforceable) disciplines will result in greater efficiency (lower costs). Such an understanding exists when it comes to tariffs and related border barriers, but much less so when it comes to domestic regulatory policies.

It is important to recognize that trade agreements may not be useful mechanisms to support effective cooperation between regulators, even if trade negotiators have the best of intentions. Much depends here on what the agreement seeks to do and the safeguards that are included to provide assurances that regulatory goals will not be undercut. The public backlash against TTIP in the EU was largely driven by concerns that greater integration of the transatlantic marketplace may result in an erosion of regulatory regimes in areas that are of great importance to significant segments of the EU population - such as the use of genetically modified organisms (GMOs) and specific food standards (Young, 2016). Regulatory cooperation is likely to be more easily pursued if it involves a bottom-up process that is driven by regulatory agencies, as opposed to being imposed top down as an element of a trade agreement. A useful prescription in this regard is to apply the principle "first, do no harm" and to concentrate on incorporating measures in trade agreements that can be defended as improving the ability of regulators to do their job better. That is, the aim should be empowerment of regulatory bodies rather than imposing restrictions on them (or being seen to be doing so even if that is not the intention).

From a trade perspective, international cooperation on regulation arguably should center on improving the transparency of applied policies; supporting analysis of the trade (and investment) effects of specific types of regulation; giving regulators a mandate that encourages (permits) them to design regulations that do not unnecessarily restrict trade; and doing more to ensure that the process of international standardssetting and norms-setting occurs with greater attention given to the potential trade impacts. Measures taken by the trade community to achieve these objectives should not affect the ability of regulators to do their job.

Transparency. This is a core feature and function of the WTO. The regular work of the TBT and SPS Committees, including notifications and the opportunity to 
raise specific concerns, can be emulated in other areas of regulation. Here an obvious area to prioritize are services and regulations that impact on the ability of firms to supply and consumers to buy products that are connected to/use "the cloud" (data localization requirements, etc.) The relevant GATS bodies have not ignored issues of domestic regulation (see above), but much more could be done to map out the policies that WTO Members are pursuing. The recent joint venture with the World Bank to maintain and update a database on services trade policies - the Services Trade Restrictiveness Indicators (STRI) - is a good first step, but this is mostly limited to policies that are discriminatory and do not cover domestic regulation. It is unlikely that this can rely only on notifications - it will require a pro-active effort by the WTO Secretariat, working with other international organizations.

Much greater transparency is also needed as regards the operation and effects of PTAs. Insofar as PTAs give rise to innovative approaches to attenuate the marketsegmenting effects of differences in regulatory policies, they can help all countries identify approaches that can usefully be emulated. All WTO Members have a strong interest in understanding what PTAs end up doing and achieving, including their implementation, utilization and enforcement. Documenting and analyzing the approaches that are used in PTAs to reduce costs of regulatory heterogeneity would not only improve transparency per se, but can also inform a process of learning about what works and what does not and perhaps identify specific features of cooperation in PTAs that might be multilateralized. There have been some moves in this direction on an ad hoc basis; for example, the GATS Working Party on Domestic Regulation conducted a dedicated discussion on domestic regulation in regional trade agreements in 2014.

Learning: analysis and deliberation. As noted previously, there is often relatively little, if any, effort by national regulators and international standards-setting bodies to consider the trade impacts of regulatory requirements and alternative approaches that might have less negative effects while not impacting on the probability that regulatory objectives will be realized. There is also arguably more that can be done to understand how the universe of regulatory measures maps into the categories defined in Figure 1 and the potential efficacy of the different types of international regulatory cooperation summarized in Figure 2. There would appear to be significant scope to use the WTO bodies that already have a mandate to discuss regulatory policies (TBT, SPS, services) to commission analysis of trade effects and to engage more regularly with the business community in discussions aimed at identifying where greater effort to pursue regulatory cooperation - which need not occur through 
the WTO - could have a significant impact on trade costs. Currently there is too little scope for engagement with the business community within WTO bodies. There is more attention for this in recent PTAs like CETA, but even there the extent to which business is part of regulatory deliberation arguably is too limited (Hoekman, 2015).

Give regulators a mandate to consider trade effects. A simple yet powerful change that WTO and PTA members could seek to achieve is to agree that regulatory processes include an assessment of trade effects - perhaps as part of broader regulatory impact assessments that are generally considered to be an element of good practice. This is already "on the table" in the deliberations on a voluntary code of good practice in the WTO TBT Committee. If no consensus can be achieved there - and given that in other areas of regulation, this agenda is being pursued - one way proponents could consider moving forward is through plurilateral approaches (see below). In order to increase the prospects that trade impact assessments are made, regulatory agencies should be provided with the necessary (financial) resources so that such an effort would not crowd out (or be seen to crowd out) other activities. Incorporation of "trade effects assessment" language in trade agreements is in itself an instrument through which regulatory agencies can lay claim on additional resources from the government that are needed to fulfil the commitment.

Engaging with international standards-setting bodies. More generally, there is a clear case for more regular interaction with international regulatory bodies. Again this is something that already occurs on an ad hoc basis. For example, representatives of the Basel Committee on Banking Supervision, the Financial Stability Board, the International Association of Insurance Supervisors and the International Organizations of Securities Commissions have been invited periodically by the GATS Committee on Trade and Financial Services to present recent developments in the area of international regulatory norms and initiatives in the financial sector and discuss possible implications for trade in financial services. However, this is largely limited to one-way information transmission. What would arguably make a difference is a greater effort by WTO Members - who are all represented in international standards-setting bodies - to include a focus on the trade effects of new international norms and standards.

\section{More plurilateral cooperation under the umbrella of the WTO?}

Going beyond greater transparency, analysis and interacting with international standards-setting bodies, at the level of the WTO consideration should be given to 
facilitating more small-group cooperation on regulatory policies. Abstracting from informal discussion or working groups, there are two main alternative mechanisms for groups of WTO members to collaborate on an issue-specific agenda of common interest: conclusion of a Plurilateral Agreement (PA) under Article II.3 WTO, and so-called critical mass agreements (CMAs) (Lawrence, 2006). CMAs are agreements in which negotiated disciplines apply to only a subset of countries, but benefits are extended on a nondiscriminatory basis to all trading partners. An example of a CMA is the Information Technology Agreement (ITA) - a so-called "zero-for-zero" agreement in which a group of countries agree to eliminate tariffs for a specific set of products and inscribe these commitments into their WTO schedules. CMAs have also been concluded to facilitate trade in services. Examples are agreements on basic telecommunications and on financial services that have been concluded under the General Agreement on Trade in Services. The commitments defined in these agreements apply only to signatories, but their benefits accrue to all WTO members as the disciplines are applied on an nondiscriminatory basis.

PAs differ from CMAs in that they may be applied on a discriminatory basis that is, benefits need not be extended to non-signatories. There are currently only two PAs incorporated into the WTO: the Agreement on Civil Aircraft and the Agreement on Government Procurement. PAs are similar to PTAs in being designed to discriminate against countries that are not members, but an important difference with PTAs is that in the case of a PA the discrimination is limited to one policy area (the subject matter of the agreement). PTAs in contrast cover many sectors and policy areas. Indeed, WTO rules require that PTAs cover substantially all trade in goods and/or have substantial sectoral coverage of services.

PTAs differ from both PAs and CMAs in tending to be closed clubs - most PTAs do not include an accession clause. Those PTAs that do allow for accession often restrict it to countries in a specific geographic region. This helps explain the proliferation of PTAs - a new agreement often must be negotiated between members of any given PTA and a non-member, because it is not possible for a non-member to join an existing trade agreement. Both CMAs and PAs are open in the sense that in principle any WTO Member can join if it wants to and is able to satisfy whatever disciplines are embodied in the agreement.

There are good reasons for WTO members to attempt to do more via plurilateral initiatives as these allow countries with an interest in cooperating on a policy area to do so without being held back by countries that are not interested in doing so. Arguments

(C) Korea Institute for International Economic Policy 
that have been raised against more cooperation on a plurilateral basis under the WTO umbrella revolve around their potential precedent-setting and negative spillover effects on countries that decide not to join, the fact that rules, even if they apply only to signatories will be defined by those that initially negotiate an agreement, and possible resource implications for the WTO Secretariat. Another downside risk associated with plurilateral initiatives is that they may reduce the ability of (scope for) countries to pursue issue-linkage strategies that are needed for developing countries to obtain concessions in areas that are of importance to them. Finally, and most concern to non-participants is that plurilaterals that take the form of PAs will be discriminatory.

These considerations are less salient for CMAs than for PAs and the former will apply on a nondiscriminatory basis. However, as discussed in greater depth by Hoekman and Mavroidis (2015), CMAs and PAs are unlikely to have significant negative welfare impacts on non-signatories. In the case of CMAs this is relatively unambiguous because they will apply on a nondiscriminatory basis and do not impose any obligations on nonparticipants. In the case of PAs the potential downside risks are low given that they must be approved by the WTO Membership as a whole. Insofar as there are serious concerns on the part of non-signatories, they can block such agreements. In assessing the case for plurilateral initiatives in the WTO context it is important to consider the counterfactual. In practice this will comprise countries negotiating PTAs that are inherently discriminatory. Despite PTAs being subject to review by the WTO, there is no effective ex ante discipline on their content: WTO review is limited to the supply of information. Both CMAs and PAs are more transparent than PTAs as they involve formal scheduling of commitments by signatories and regular reporting on activities to the WTO Membership as a whole. They imply less dispersion in rules and approaches - and thus transactions costs and trade diversion - than PTAs. Indeed, they offer a way to multilateralize elements of what may be covered in PTAs. Multiple PTAs dealing with the same subject matter often do so in ways that imply that the rules of the game for firms differ depending on the PTA that applies for a given trade flow.

There is no formal constraint on the ability of a club of WTO Members to pursue CMAs that involve deepening of disciplines on policies that are already subject to WTO rules, as long as they are willing to apply these on an MFN basis (Hoekman and Mavroidis, 2017). There is, however, a major constraint that impedes the feasibility of pursuing new PAs under WTO auspices: incorporation of a PA into the WTO 
requires unanimity "exclusively by consensus." 18 The consensus requirement is an important safeguard to ensure that PAs do not negatively affect non-signatories. That said, it is also a major disincentive for countries to pursue new PAs and thus acts as an incentive for countries to take the PTA route. Hoekman and Mavroidis (2015; 2017) argue consideration be given to exploring ways in which countries can continue to ensure that new PAs will not have detrimental spillover effects without giving just one or a small group of nations veto power. They suggest that WTO Members set up a task force on a code of conduct for new plurilateral agreements that apply to and benefit only signatories and consider replicating a GATS provision permitting WTO Members to make additional commitments in the GATT, so as to facilitate the negotiation of new CMAs that deal with regulatory policies that affect trade in goods. Such a code would establish basic principles that new club-based agreements need to satisfy to be consistent with the principles of the multilateral trading system, as well as substantive criteria for the rejection of proposals to pursue such cooperation under WTO auspices.

\section{CONCLUDING REMARKS}

The gradual reduction of tariffs as part of a more general process to open economies to international trade and investment flows, in conjunction with technological changes that are permitting the digitization of products and increasing the share of services in global production, have greatly increased the impacts of differences in domestic regulation of products and production processes. The future international trade agenda is likely to become largely a regulatory agenda, the challenge being to devise mechanisms to reduce the costs of differences in regulatory regimes while at the same time ensuring that this does not erode the likelihood of attaining the regulatory objectives that have been established by the polities of countries that engage in trade.

In principle, regulatory cooperation may bolster the ability of regulators to attain regulatory objectives if it is designed with that objective in mind. Indeed, in practice this is likely to be a necessary condition for cooperation to be feasible. A key question for governments is whether trade agreements are a useful instrument to guide regulatory

18 See Article X.9 of the Agreement Establishing the WTO.

(C) Korea Institute for International Economic Policy 
cooperation and if so, how regulatory matters should be addressed in trade agreements. In some areas, such as technical regulation of products, there are now well-established and reasonably effective mechanisms in the WTO through which the potential negative externalities of differences in standards can be identified, discussed and attenuated. In many other areas of regulation - such as prudential regulation of services, "private standards” systems that apply to international production processes, or standards of protection of worker rights and the environment - WTO members have yet to put in place such mechanisms. The same is largely true of PTAs - while there is much discussion of new vintage PTAs as instruments for regulatory convergence, to date steps to address such matters have been limited.

Neither PTAs nor the WTO engage on the substance of regulatory norms - the focus is on the trade-impeding effects of differences in regulatory standards. Cooperation on substantive norms - international standardization - is left to specialized bodies in which regulators interact. These bodies tend to be technical and focused on defining the means to achieve specific regulatory objectives (health, safety, etc.). They generally do not consider the potential impacts on trade. One role that the WTO could play looking forward is doing more to ensure that international regulatory efforts consider trade effects when developing new international norms. More generally, the WTO (and trade agreements more generally) could be used as a focal point for encouraging regulators to interact with each other and to consider cooperation that enhances their joint ability to attain regulatory objectives at lower cost. The suggestions made above regarding the form this could take illustrate the potential positive role that trade agreements can play. Whether they will be pursued depends importantly on the stance taken by international business. A necessary condition is strong advocacy by international business for greater engagement by governments in the WTO to address negative regulatory spillovers.

\section{REFERENCES}

Arnold, P. 2005. "Disciplining Domestic Regulation: The World Trade Organization and the Market for Professional Services,” Accounting, Organizations and Society, vol. 30, no. 4, pp. 299-330. Bismuth, R. 2010. "Financial Sector Regulation and Financial Services Liberalization at the Crossroads: The Relevance of International Financial Standards in WTO Law,” Journal of World Trade, vol. 44, no. 2, pp. 489-514. 
Bollyky, T. 2012. Regulatory Coherence in the Trans-Pacific Partnership Talks. In Lim, C. L., Elms, D. and P. Low. (eds.) The Trans-Pacific Partnership: A Quest for a 21st Century Trade Agreement. Cambridge, UK: Cambridge University Press. pp. 171-186.

Canada. 2014. Canada-US Regulatory Cooperation Council: Joint Forward Plan. Ottawa: The Council.

Cardoso, D., Mthembu, P., Venhaus, M. and M. V. Garrido. (eds.) 2013. The Transatlantic Colossus: Global Contributions to Broaden the Debate on the EU-US Free Trade Agreement. Berlin: Berlin Forum on Global Politics.

Coglianese, C. and E. Mendelson. 2010. Meta-Regulation and Self-Regulation. In Baldwin, R., Cave, B. and M. Lodge. (eds.) The Oxford Handbook of Regulation. Oxford: Oxford University Press.

Government of Canada. 2017. Text of the Comprehensive Economic and Trade Agreement. Ottawa: Global Affairs Canada. <http:/international.gc.ca/trade-commerce/trade-agreements- accordscommerciaux/agr-acc/ceta-aecg/text-texte/toc-tdm.aspx?lang=eng> (accessed December 10, 2017)

Hoekman, B. 2015. Trade Agreements and International Regulatory Cooperation in a Supply Chain World. In Tapp, S., van Aasche, A. and R. Wolfe. (eds.) Redesigning Canadian Trade Policies for New Global Realities. Ottawa: IRPP. pp. 1-29.

. 2016. The Bali Trade Facilitation Agreement and Rulemaking in the WTO: Milestone, Mistake or Mirage?. In Bhagwati, J., Krishna, P. and A. Panagariya. (eds.) Challenges Facing the World Trading System. Cambridge, MA: MIT Press.

. 2017. Behind-the-Border Policies: Regulatory Cooperation and Trade Agreements.

In Primo Braga, C. A. and B. Hoekman (eds.) Future of the Global Trade Order. San Domenico Di Fiesole: European University Institute.

Hoekman, B. and P. C. Mavroidis. 2015. "Embracing Diversity: Plurilateral Agreements and the Trading System,” World Trade Review, vol. 14, no. 1, pp. 101-116.

. 2016. A Technical Barriers to Trade Agreement for Services?. In Sauvé, P. and M. Roy. (eds.) Research Handbook on Trade in Services. Northampton, MA: Edward Elgar. . 2017. "MFN Clubs and Scheduling Additional Commitments in the GATT: Learning from the GATS,” European Journal of International Law, vol. 28, no. 3, pp. 387-407.

Hoekman, B. and C. Sabel. 2017. Trade Agreements, Regulatory Sovereignty and Democratic Legitimacy. EUI Working Paper, no. RSCAS 2017/36.

Horn, H., Mavroidis, P. C. and E. Wijkström. 2013. "In the Shadow of the DSU: Addressing Specific Trade Concerns in the SPS and TBT Committees,” Journal of World Trade, vol. 47, no. 4, pp. 729-760.

Humphrey, J. 2012. "Convergence of US and EU Production Practices under the New FDA Food Safety Modernization Act,” World Economy, vol. 35, no. 8, pp. 994-1005.

Laffont, J.-J. 1994. “The New Economics of Regulation Ten Years After,” Econometrica, vol. 62, no. 3, pp. 507-537.

Lawrence, R. 2006. "Rulemaking Amidst Growing Diversity: A ‘Club of Clubs’ Approach to WTO Reform and New Issue Selection,” Journal of International Economic Law, vol. 9, no. 4, pp. 823-835.

Messerlin, P. 2014. Negotiating Mega-Agreements: Lessons from the EU. RCSAS Working Paper, no. 2014/112. Florence: European University Institute. 
Organisation for Economic Co-operation and Development (OECD). 2013. International Regulatory Co-operation: Addressing Global Challenges. Paris: OECD.

. 2014. Draft Study on MRAs: Stocktaking and Case Studies. GOV/RPC(2014)12. Paris: OECD.

Pelkmans, J. 2012. Mutual Recognition: Economic and Regulatory Logic in Goods and Services. Bruges European Economic Research Papers, no. 24/2012. Bruges: College of Europe.

Posner, R. 2013. The Concept of Regulatory Capture: A Short, Inglorious History. In Carpenter,

D. and D. Moss. (eds.) Preventing Regulatory Capture: Special Interest Influence and How to Limit It. Cambridge, UK: Cambridge University Press.

Sabel, C. and W. Simon. 2011. "Minimalism and Experimentalism in the Administrative State,” Georgetown Law Journal, vol. 100, pp. 53-93.

Steger, D. 2012. "Institutions for Regulatory Cooperation in 'New Generation' Economic and Trade Agreements,” Legal Issues of Economic Integration, vol. 39, no. 1, pp. 109-126.

Stigler, G. 1975. The Citizen and the State: Essays on Regulation. Chicago: University of Chicago Press.

Verdier, P.-H. 2011. “Mutual Recognition in International Finance,” Harvard International Law Journal, vol. 52, no. 1, pp. 56-108.

Vogel, D. 2012. The Politics of Precaution: Regulating Health, Safety, and Environmental Risks in Europe and the United States. Princeton, NJ: Princeton University Press.

Wijkström, E. 2015. The Third Pillar: Behind the Scenes, WTO Committee Work Delivers. The E15 Initiative. <http://e15initiative.org/wp-content/uploads/2015/07/E15-RegulatoryWijkstrom-final.pdf $>$ (accessed November 7, 2017).

Wijkström, E. and D. McDaniels. 2013. "Improving Regulatory Governance: International Standards and the WTO TBT Agreement,” Journal of World Trade, vol. 47, no. 5, pp. 1013-1046.

World Trade Organization (WTO). 2015. The WTO at Twenty: Challenges and Achievements. Geneva: WTO.

Young, A. 2016. "Not Your Parents’ Trade Politics: The Transatlantic Trade and Investment Partnership Negotiations,” Review of International Political Economy, vol. 23, no. 3, pp. 345-378.

First version received on 9 January 2018

Peer-reviewed version received on 19 February 2018

Final version accepted on 30 August 2018 reproduction in any medium, provided you give appropriate credit to the original author (s) and the source, provide a link to the Creative Commons license. 